\title{
Strength and permeability recovery of tuffisite-bearing andesite
}

\author{
S. Kolzenburg ${ }^{1}$, M. J. Heap ${ }^{2}$, Y. Lavallée ${ }^{3}$, J. K. Russell ${ }^{1}$, P. G. Meredith ${ }^{4}$, and D. B. Dingwell ${ }^{3}$ \\ ${ }^{1}$ Volcanology and Petrology Laboratory, Earth and Ocean Sciences, University of British Columbia, 6339 Stores Road, V6T \\ 2B4 Vancouver, BC, Canada \\ ${ }^{2}$ Laboratoire de Déformation des Roches, Institut de Physique de Globe de Strasbourg (UMR 7516 CNRS, Université de \\ Strasbourg/EOST), 5 rue René Descartes, 67084 Strasbourg cedex, France \\ ${ }^{3}$ Earth and Environment, LMU - University of Munich, Theresienstr. 41/III, 80333 Munich, Germany \\ ${ }^{4}$ Rock and Ice Physics Laboratory, University College London, Gower Street WC1E 6BT London, UK \\ Correspondence to: S. Kolzenburg (skolzenburg@eos.ubc.ca)
}

Received: 3 March 2012 - Published in Solid Earth Discuss.: 7 March 2012

Revised: 13 June 2012 - Accepted: 15 June 2012 - Published: 12 July 2012

\begin{abstract}
Tuffisites, the products of subsurface fragmentation, transport and deposition, are common in explosive volcanic environments. Their study provides direct insight to the mechanical processes operating within volcanic conduits. Here we document the influence of the presence of coherent tuffisite veins on the physical properties of andesitic rocks. We find that (1) compressive strength is unaffected by the presence and/or orientation of tuffisites, (2) permeability doubles when tuffisites are oriented favorably (at $45^{\circ}$ to the fluid flow direction), and (3) ultrasonic wave velocities show a continuous increase with depth, independent of vein presence and orientation. Although the influence of tuffisites on andesitic rock properties determined here is modest, we emphasize that the material tested represents the post-eruptive state of tuffisite. Thus, these results likely delineate the upper and lower boundaries of strength vs. permeability and porosity, respectively. Our evidence suggests that, via compaction and lithification, tuffisites may restore the strength of the volcanic host-rocks to that of their pre-tuffisite values.
\end{abstract}

\section{Introduction}

Tuffisites are common in exhumed volcanic environments and may provide a direct record of the subsurface processes operating in a conduit during explosive eruptions (Lavallée et al., 2012a). Tuffisites have been reported for a wide range of chemical compositions and diverse volcanic environments, including basaltic diatremes (Cloos, 1941), andesitic fossil conduits (Noguchi et al., 2008), and rhyolitic conduits
(Tuffen et al., 2003). They were first defined by Cloos (1941) who described them as follows:

"The host rock seems tuffisized, i.e. infiltrated by the tuff along its finest cracks and crevices and intimately mixed with it."..."Appearance and color of such mixed rock types "tuffisites" is governed by the nature of the host rock"... "All observations point towards this tuffisitation taking place during the main phase of volcanism through penetration of gases into the surrounding rock."

This makes them inherently different from rocks occurring within cataclastic shear zones enveloping lava domes and spines, such as described at Mt. St. Helens, USA (Cashman et al., 2008; Kendrick et al., 2012; Kennedy et al., 2009) and Mt. Unzen, Japan (Nakada et al., 1999). Key differences include geometry and internal structures. Tuffisites create or use pre-existing fracture networks producing an anastomosing pattern of ash-filled veins (Stasiuk et al., 1996; Tuffen et al., 2003), whereas shear zones tend to form linear, or in the case of erupting lava spines, annular patterns (Cashman et al., 2008; Friedlander, 2012). Structurally, tuffisites are massive or show bedding structures resulting from the transport in a fluidized state (Tuffen et al., 2003), whilst shear zones are foliated and/or commonly develop a C-S-shear fabric (Kendrick et al., 2012). One does not however preclude the other; tuffisites can potentially be sourced from shear zones simply by later gas fluidization of the fine-grained cataclastic material.

The fragmental origin of tuffisites might suggest that their formation will increase the porosity and permeability (Castro et al., 2012) and reduce the strength (Paterson and Wong, 


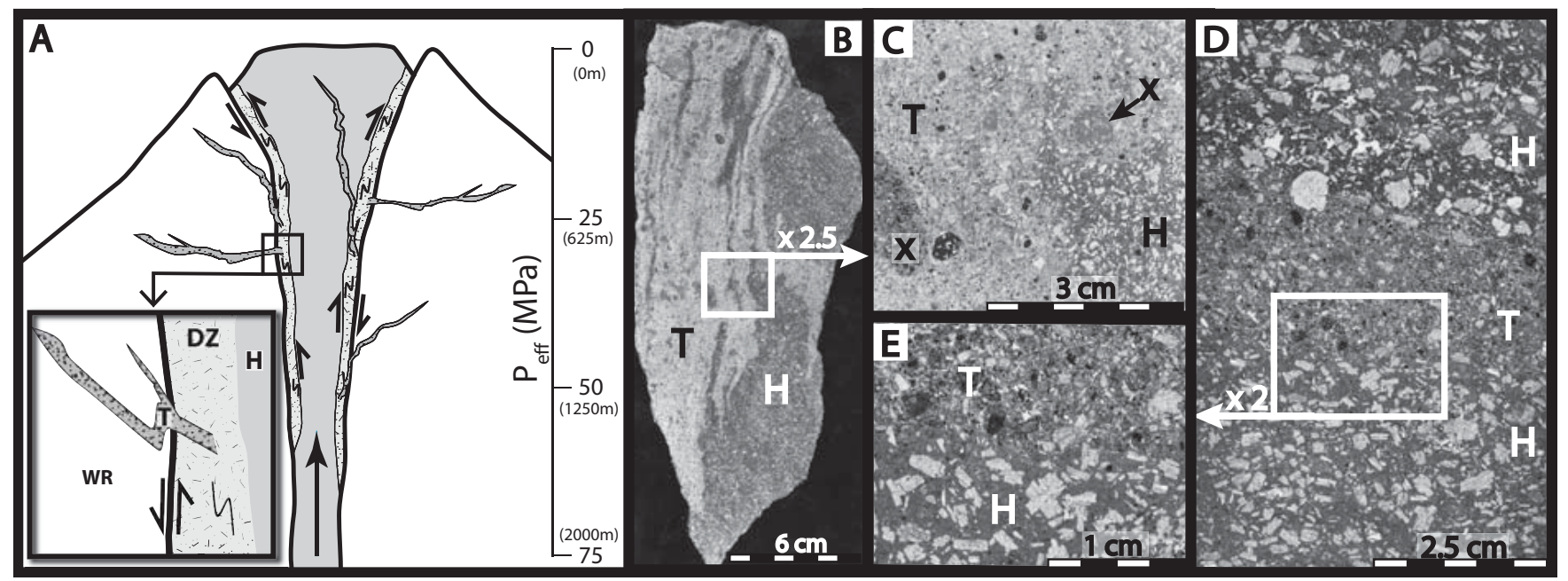

Fig. 1. (A) Cartoon of a dome building eruption showing the occurrence of tuffisite veins in volcanic edifices. (Tuffisite veins have been reported near the surface (Tuffen et al., 2003) and up to more than 500 meters depth (Heiken et al., 1988)) (B) Photograph of a slab cut from a tuffisite $(\mathrm{T})$ bearing sample of andesite $(\mathrm{H})$ from Colima, Mexico. (C) Scanned thin section prepared from the slab in (B) showing rounded lithic clasts $(\mathrm{X})$. (D) Scanned thin section of an approx. $1 \mathrm{~cm}$ wide tuffisite vein. $(\mathbf{E})$ Zoom on the interface between host rock $(\mathrm{H})$ and tuffisite $(\mathrm{T})$.

2005) of otherwise competent host rock. Ultimately, the strength of the conduit-filling material and the permeability of the volcanic edifice are likely to be key properties governing both eruption style (effusive or explosive (Collinson and Neuberg, 2012; Kennedy et al., 2010)) and dynamics (catastrophic or continuous; Taisne and Jaupart (2008)). Here we present the first experimental study on the permeability, porosity, uniaxial compressive strength (UCS), and P-and Swave velocities $\left(V_{\mathrm{p}}\right.$ and $\left.V_{\mathrm{s}}\right)$ of andesite containing tuffisite veins.

\section{Experimental materials and methodology}

\subsection{Experimental materials}

The 2005 eruption of Volcán de Colima in Mexico disrupted parts of the lava domes sitting in the upper conduit (Lavallée et al., 2012b) and provided a unique opportunity to collect tuffisite-bearing andesite from an active volcano. The rocks described here were collected as loose blocks selected from the pyroclastic flows of the 2005 explosive activity. Thus their exact origin in the rapidly ascending magma column remains a subject of uncertainty.

Thin sections of these rocks were prepared perpendicular to the long axis of the veins and orthogonal to each other. The host rock is a coherent porphyritic andesite. The phenocryst assemblage (Fig. 1) comprises 30 vol.\% plagioclase ( 0.2 to $2.5 \mathrm{~mm}$ length), 10 vol.\% pyroxene (0.1- to $2-\mathrm{mm}$ diameter), and less ( $\sim 5$ vol.\%) (average $0.1 \mathrm{~mm}$ ) opaque oxides. The groundmass comprises needle shaped, microcrystalline plagioclase (average 25 vol.\%), pyroxene (average 15
Table 1. Physical properties of the sample collection.

\begin{tabular}{llll}
\hline $\begin{array}{l}\text { Sample } \\
\text { Name }\end{array}$ & $\begin{array}{l}\text { Skeletal Density } \\
\left(\mathrm{g} \mathrm{cm}^{-3}\right)\end{array}$ & $\begin{array}{l}\text { Porosity } \\
(\%)\end{array}$ & $\begin{array}{l}\text { UCS at } 940^{\circ} \mathrm{C} \\
(\mathrm{MPa})\end{array}$ \\
\hline COL-TUF-CR & 2.786 & 7.76 & 114.5 \\
COL-TUF-P2 & 2.782 & 9.07 & 119.1 \\
COL-TUF-P3 & 2.812 & 9.83 & 123.9 \\
COL-TUF-A1 & 2.798 & 8.81 & 127.0 \\
COL-TUF-A2 & 2.864 & 10.97 & 138.4 \\
\hline
\end{tabular}

vol.\%), opaque oxides (average 10 vol.\%) and minor (average 5 vol. \%) interstitial glass. The bulk porosities for all samples of andesite with and without veins range from $7.8 \%$ to $11 \%$ (Table 1), which is at the low-porosity end of the porosity distribution of the erupted dome material (Lavallée et al., 2012b).

The thicknesses of the tuffisite veins vary from approximately 3 to ca. $50 \mathrm{~mm}$. The tuffisites tested in this study are holocrystalline and consist of coherent fragmental material. The crystal size within the veins generally differs from the host rock. Large plagioclase and pyroxene phenocrysts generally appear broken several folds within the veins. Iron oxides are sometimes larger in the veins than in the host rocks, suggesting that they have been transported from another area (with a different petrographic equilibrium). The contact between the host rock and the veins is generally irregular. Petrographic analysis suggests the tuffisite being devoid of glass, dominated by $\sim 80 \mathrm{vol} . \%$ fragments of crystals (plagioclase, pyroxene and opaque oxides) between $0.25 \mathrm{~mm}$ and $1 \mathrm{~mm}$, and $20 \mathrm{vol} . \%$ of larger ( 3 to $20 \mathrm{~mm}$ ), comminuted 
and rounded lithic clasts of varying composition. No fabrics indicative of shear (i.e., C-S fabric like described in fault gouges by Cashman et al. (2008) and Kendrick et al. (2012)) or preferred orientation of clasts is observed in these rocks. Devitrification textures or shapes suggestive of glass shards were not identified. The absence of volcanic glass was confirmed by dilatometric measurements of tuffisite vein material; during heating to $1000^{\circ} \mathrm{C}$ at a rate of $10^{\circ} \mathrm{C} \mathrm{min}^{-1}$, the expansion of samples was linear suggestive of a fully crystalline material with no softening characteristic of glass. The diversity of lithic clasts suggests that the vein material is a mixture of autochthonous and allochthonous material (see Fig. 1).

From these blocks, cylindrical (25-mm diameter and 50mm length) core samples were drilled perpendicular and at an angle $\sim 45^{\circ}$ to the tuffisite veins. Orientating the tuffisite vein at 45 degrees allows for preferred stress concentration along the tuffisite veins during compression. The orientations of the tuffisite veins are somewhat irregular and the actual angles may vary from the reported values by $\pm 5^{\circ}$. The sample core ends were ground flat and parallel to each other in order to reduce edge effects during deformation.

\subsection{Hydrostatic experiments}

Sample porosity, permeability, and ultrasonic wave velocity measurements were made under increasing confining pressures in a $300 \mathrm{MPa}$ hydrostatic pressure vessel equipped with two $70 \mathrm{MPa}$ servo-controlled pore fluid intensifiers or volumometers located in the Rock \& Ice Physics Laboratory (RIPL) at University College London (Fig. 2b). We selected one tuffisite-free core sample (from the same tuffisite-bearing block) to serve as a baseline for comparison (COL-TUF-CR). Four andesite samples containing similar connected porosities (see Table 1) were carefully selected for experimentation: two cores containing tuffisites oriented perpendicular to the flow direction (COL-TUF-P2 and -P3) and two that have veins oriented at 45 degrees to the flow direction (COL-TUFA1 and -A2). On that basis, we suggest that any differences in their measured physical properties should therefore be related solely to the orientation of the tuffisites. The effects of sample heterogeneity are therefore considered to be of second order.

The two volumometers were used in an "upstream" and "downstream" configuration, with a $1 \mathrm{MPa}$ pressure difference across the jacketed sample to provide the flow required to calculate permeability using Darcy's law, once steadystate flow had been established. For the experiments in this study, the pore pressure $\left(P_{\mathrm{p}}\right)$ was kept at 9.5 and $10.5 \mathrm{MPa}$ in the two pore pressure intensifiers, respectively. Confining pressure $\left(P_{c}\right)$ was applied by pumping silicon oil into the pressure vessel at $15 \mathrm{MPa}, 20 \mathrm{MPa}$ and then every $10 \mathrm{MPa}$ increment up to $60 \mathrm{MPa}$, yielding effective confining pressures $\left(P_{\text {eff }}\right)$ between 5 and $50 \mathrm{MPa}$. For the purpose of this study we apply the simple effective pressure law of $P_{\text {eff }}=$

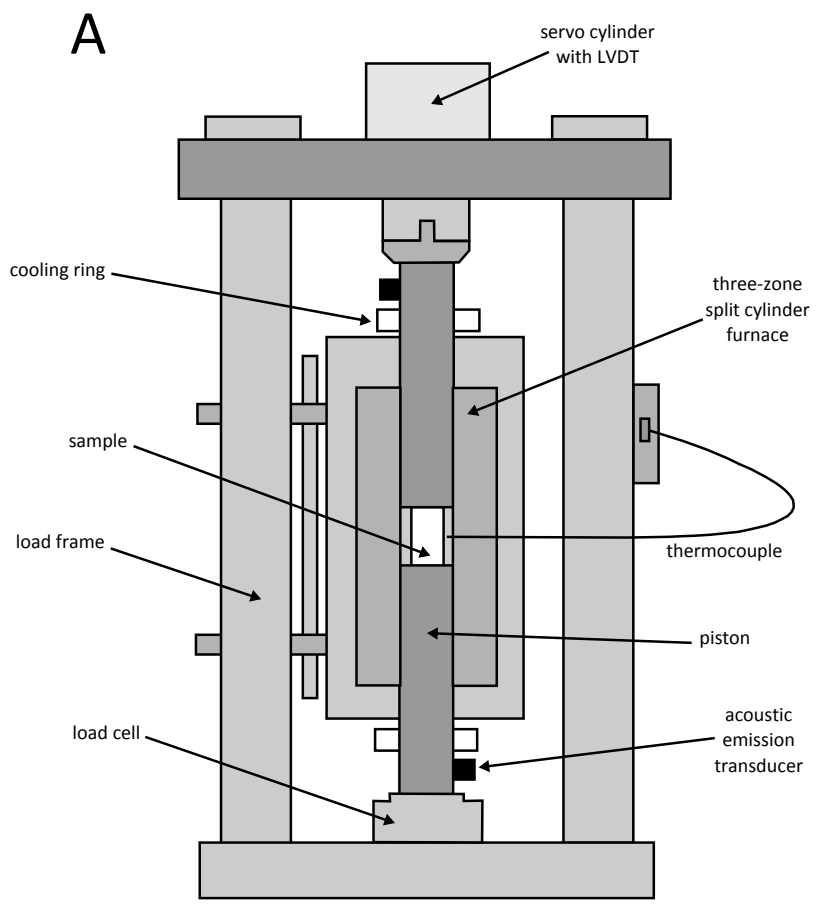

B

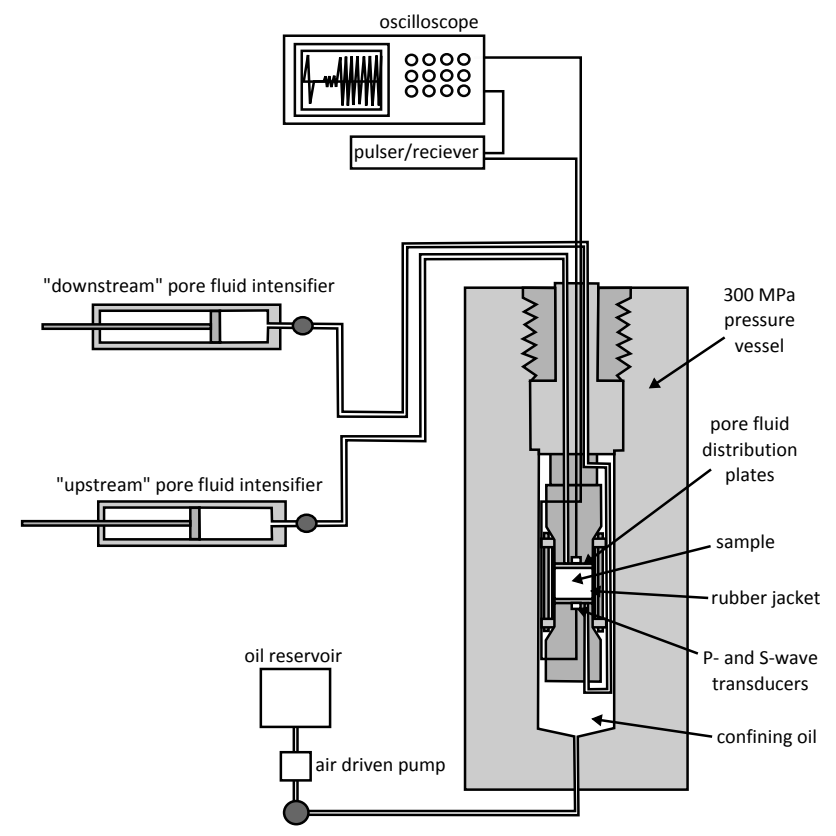

Fig. 2. (A) Schematic of the high temperature uniaxial press, described in detail by (Hess et al., 2007), at the Ludwig-Maximilians University in Munich (LMU). (B) Schematic of the $300 \mathrm{MPa}$ hydrostatic pressure vessel equipped with two $70 \mathrm{MPa}$ servo-controlled pore fluid intensifiers or volumometers located in the Rock \& Ice Physics Laboratory (RIPL) at University College London (UCL). 
$P_{\mathrm{c}}-\alpha P_{\mathrm{p}}$, assuming that $\alpha=1$ (Guéguen and Palciauskas, 1994). The permeability was measured for each pressure increment, together with ultrasonic wave velocities and sample porosity. Ultrasonic wave velocity measurements were made via piezoelectric $\mathrm{P}$ - and $\mathrm{S}$-wave transducer crystals housed within the sample end caps using an Agilent Technologies $1.5 \mathrm{GHz}$ "Infiniium" digital storage oscilloscope and a JSR DPR300 35MHz ultrasonic pulser/receiver.

The sample porosity was calculated by (1) isolating one of the pore pressure intensifiers from the sample, (2) setting the open pore pressure intensifier to $10 \mathrm{MPa}$ and allowing the sample time to equilibrate, and (3) increasing the confining pressure whilst monitoring the displacement of the open pore pressure intensifier. The porosity was then recalculated using the volume of water expelled from the rock (e.g., Benson et al., 2005). Finally, we converted our values of $P_{\text {eff }}$ into depths (h) using the simple relationship $P_{\text {eff }}=\rho g h$, where $\rho$ is the density (reported in Table 1) and $g$ is the acceleration due to gravity. Using this relationship between pressure and depth is a strong simplification, as the pressure gradients within a volcano can vary, but allows for a general approximation of the depths over which the measured properties evolve.

\subsection{Strength experiments}

The uniaxial compressive strength (UCS) was tested, independent of the porosity and permeability measurements described above, in the high-temperature uniaxial press (Fig. 2a) at Ludwig-Maximilians University in Munich (see Hess et al., 2007 for details of the apparatus). This investigation of bulk rock strength and associated mechanisms of deformation of tuffisite-bearing and tuffisite-free samples was carried out at $940^{\circ} \mathrm{C}$, as pre-eruptive temperatures were estimated at $960-1020^{\circ} \mathrm{C}$ (Reubi and Blundy, 2008 and Savov et al., 2008). A heating rate of $1^{\circ} \mathrm{C} \mathrm{min}^{-1}$ was applied until the sample reached the target temperature. The sample temperature was monitored via a thermocouple that was inserted into the sample. Once the dwell temperature was reached the upper piston was brought into contact with the sample and the sample was allowed to thermally equilibrate over one hour. The experiments started by applying a low compressive stress of $3 \mathrm{MPa}$ after which the samples were loaded at a constant rate of $2 \mathrm{MPa} \mathrm{min}{ }^{-1}$ until failure (note: such loading procedure was employed to inhibit time-dependent deformation, such as viscous flow, and thus obtain a time-independent short-term compressive strength). Simultaneously, the output of AE energy was monitored via two piezoelectric transducers with a high response band over the range $100 \mathrm{kHz}-$ $1 \mathrm{MHz}$. AE signals were recorded by a PC1-2 based MISTRAS fast data-acquisition system at a sampling rate of $10 \mathrm{MHz}$
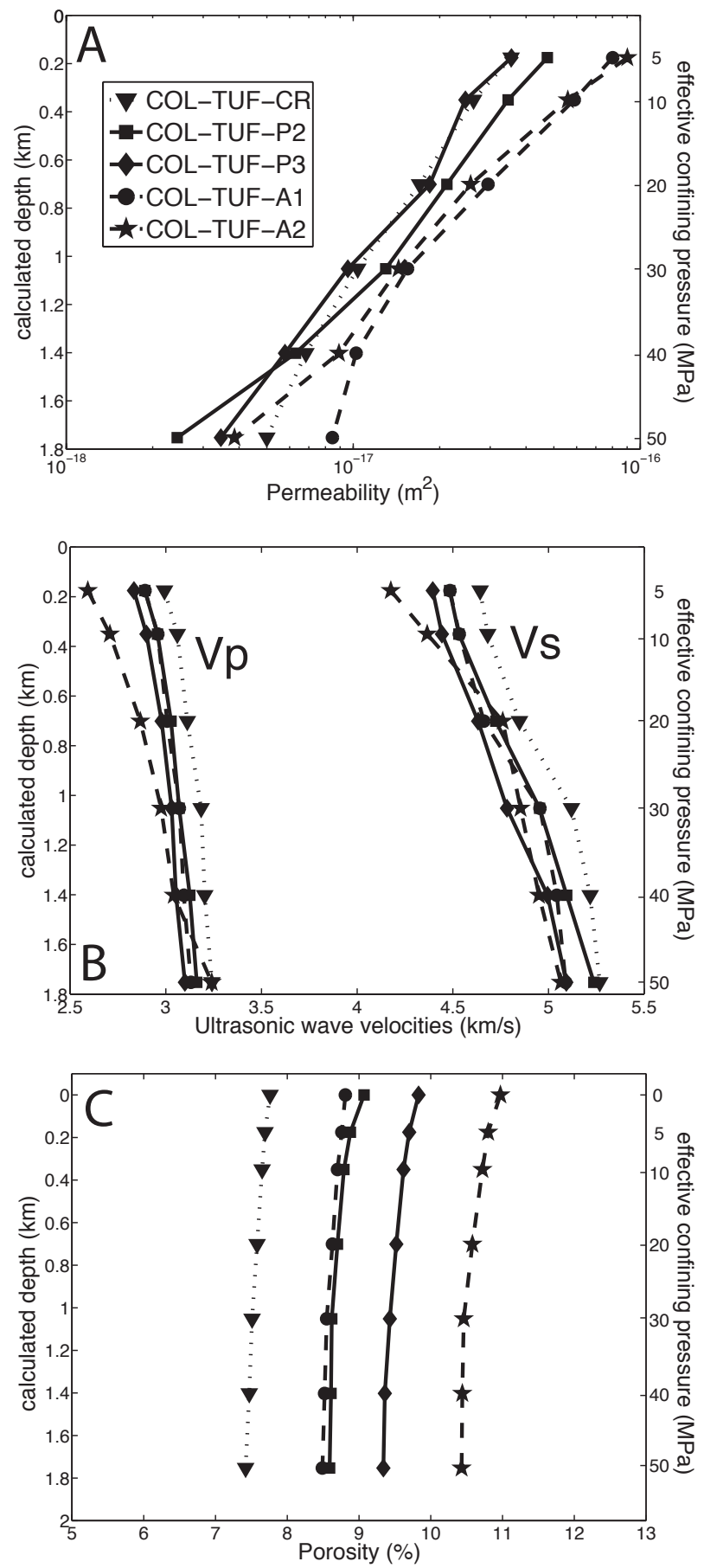

Fig. 3. (A) Depth and effective confining pressure vs. log of permeability showing a similar evolution for all samples over depth. At depths shallower than $1 \mathrm{~km}$ the permeability for samples with tuffisite veins oriented at 45 degrees to flow doubles relative to the samples with tuffisite veins oriented perpendicular to flow. (B) Depth and effective confining pressure vs. ultrasonic wave velocities showing similar evolution of both $V_{\mathrm{p}}$ and $V_{\mathrm{s}}$ with depth for all samples. (C) Depth and effective confining pressure vs. porosity showing similar evolution of porosity with increasing depth for all samples. 


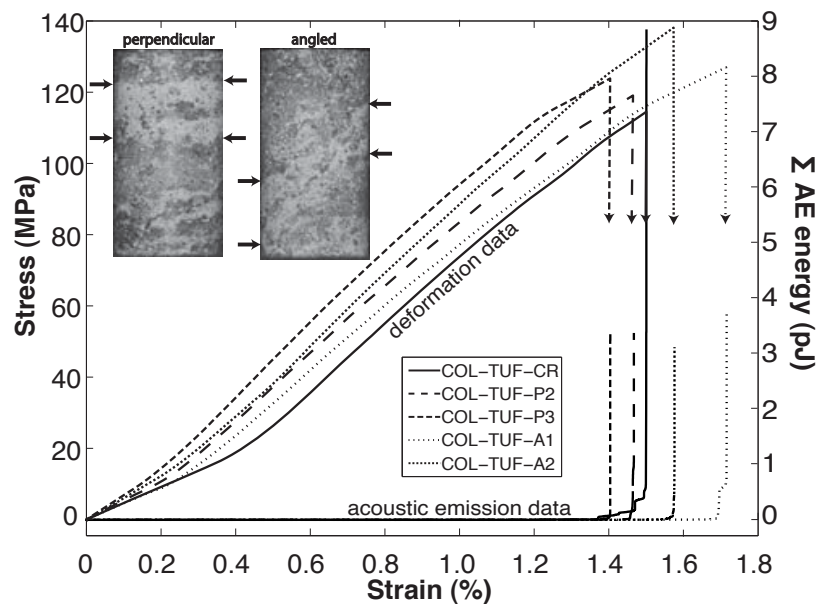

Fig. 4. Plots of stress vs. strain and cumulative AE energy ( $\Sigma \mathrm{AE})$ against strain for constant loading experiments on andesite free of tuffisite (COL-TUF-CR), with tuffisite at $45^{\circ}$ (COL-TUF-A1 and -A2) and perpendicular (COL-TUF-P2 and -P3) to sigma 1 . The UCS for all samples are constant within $17 \%$ of the maximum UCS. Inserts show examples of core samples with tuffisites at 45 degrees and perpendicular to compression. Arrows indicate the top and bottom boundaries of tuffisite veins.

\section{Results}

\subsection{Hydrostatic experiments}

Our experimental results are summarized in Fig. 3 by plotting the measured values of permeability, P- and S-wave velocity, and porosity against the model depth and the effective confining pressure. The data include measurements on samples with tuffisites at 45 degrees or perpendicular to the flow direction and on andesite without tuffisite veins. The plot shows that, as depth (i.e., $P_{\mathrm{c}}$ ) increases, both $\mathrm{P}$ - and $\mathrm{S}$-wave velocities increase (Fig. 3b) whilst the permeability (Fig. 3a) and porosity (Fig. 3c) both decrease. Over a pressure range of $50 \mathrm{MPa}$ (i.e., $\sim 200-1800 \mathrm{~m}$ depth) the samples show a $\sim 20 \%$ increase in ultrasonic wave velocities and a $\sim 5 \%$ decrease in porosity. Permeability values show a different pattern. The samples containing tuffisite veins perpendicular to flow have permeability values within the same range as the host-rock, tuffisite-free andesite. However, the permeability of samples containing tuffisite veins oriented at 45 degrees to fluid flow (the two dashed lines on the right of the plot) show a twofold decrease in permeability at depths $>220 \mathrm{~m}$. Specifically, as depth increases, the permeability of these samples decreases markedly and converges with permeability values of all other samples at depths of $\sim 1 \mathrm{~km}$.

\subsection{Strength tests}

The results of our high-temperature UCS tests are summarized by plotting both stress and cumulative AE energy $(\Sigma \mathrm{AE}$ ) against cumulative strain (Fig. 4). The data show that as the samples deform under increasing stress there is little deviation from linear elastic behavior and very little AE until immediately prior to the peak stress. While approaching peak stress, all samples reach a yield point within the last $0.2 \%$ strain. Ultimately the samples fail catastrophically which is accompanied by a large and sudden stress drop, and a dramatic increase in $\mathrm{AE}$ rate, characteristic of brittle behavior. During failure the samples were essentially pulverized; it was therefore impossible to perform any post experiment analysis on the textures within these rocks. The UCS for each sample is reported in Table 1. This experimental dataset for andesite hosting tuffisite veins (Fig. 4) establishes that at high temperatures: (1) the deformation behavior remains brittle, and (2) the UCS of the andesites is unaffected by the presence and orientation of the tuffisite veins. The UCS was found to be constant within $24 \mathrm{MPa}$ (17\% of the peak stress).

\section{Discussion}

We provide experimental data on the influence of coherent tuffisite veins on the physical properties of andesite. Our experiments have demonstrated that, for the tuffisites investigated, porosity and permeability decrease, and ultrasonic wave velocities increase with pressure down to about $2 \mathrm{~km}$, the depth at which the presence of tuffisite no longer influences the physical properties of the host andesite. Perhaps remarkably, the physical properties are largely unaffected by the presence and orientation of the coherent tuffisite veins, although those with veins oriented at 45 degrees to the flow direction are about twice as permeable at shallow depths. The reduction in porosity and permeability, and the increase in ultrasonic wave velocities with increasing pressure can be explained by the closure of pre-existing microcracks (Vinciguerra et al., 2005). Indeed, andesites from Volcán de Colima have been previously shown to contain a pervasive network of microcracks, affecting the physical response of the material (Petrakova et al., 2012). Despite the textural diversity of the andesite-tuffisite sample cores, our experiments document a profound homogeneity in UCS (about $125 \mathrm{MPa}$ ) - a characteristic that may not be expected if the tuffisites had not undergone such a high degree of compaction and lithification.

The average grain-size of the particles in the tuffisites is 250 microns with the largest particles being as large as $20 \mathrm{~mm}$ and the smallest in the micron range. Studies of granular material having comparable particle size distributions report porosity values between 17 and $27 \%$ (Zou et al., 2011). Shepherd (1989) describes the permeability of materials with similar grain sizes and varying degrees of consolidation to be between $10^{-10}$ and $10^{-13} \mathrm{~m}^{2}$. Direct measurement of the grain size distribution of tuffisite directly after formation is inhibited by their position within the edifice. The values reported above represent the span of permissive porosity and permeability for grain size distributions similar to that of the 
tuffisites tested. We suggest that the values of porosity and permeability of the tuffisite veins, immediately after their formation, should be within these ranges. The implication is that the samples tested in this study have undergone a porosity reduction of at least 9 percentage points and a decrease in permeability of four orders of magnitude. The timescales for this recovery process may be in the range of hours or days (Venkatachari and Raj, 1986), a rate enhanced when the material is subjected to confinement (Cocks, 2001). Any major influence that the presence of tuffisite veins might have on the eruptive behavior is therefore inferred to be restricted to the time period between fragmentation and healing.

We take these data as evidence that these rocks have healed and approached porosities, permeabilities, and strengths close to the initial values of the host. The holocrystalline nature of these tuffisites precludes recovery and lithification by the processes that govern welding of other, glassy, volcanic rocks (i.e., healing via structural relaxation of melt fragments; e.g., Quane and Russell (2005)). Other potential processes include, for example, hot pressing (Olgaard and Fitz Gerald, 1993), solid-state diffusion (Venkatachari and Raj, 1986) and precipitation of minerals from fluids (Taran et al., 2001) as these fragmented materials are subject to significant pressures, elevated temperatures and circulating fluids while residing in the volcanic edifice. Indeed, hot pressing at magmatic temperatures has been shown to almost annihilate porosity in ceramics on the timescale of hours (Venkatachari and Raj, 1986; Wang et al., 2002). As no precipitation minerals could be identified through petrographic analysis we find it unlikely that the precipitation of minerals from fluids percolating through these veins contributed to the solidification of these rocks. Regardless of which process is dominant, we find that tuffisites can recover their original rock properties. The proposed recovery mechanisms can act on relatively short timescales (Ben-David et al., 2010; Olgaard and Fitz Gerald, 1993; Russell and Quane, 2005; Venkatachari and Raj, 1986) and we therefore speculate that tuffisites spend most of the time in the edifice in this recovered state.

Tuffisite production within a volcano might nevertheless have wider implications for the eruptive behavior and the edifice structural stability. During fragmentation and production of the tuffisitic material, stress is released through fracturing (instead of allowing for a build up of stress leading to eruption), which in turn allows gases to escape (Castro et al., 2012), at least for the time it takes to recover host rock values of permeability. In this manner, the formation of tuffisites may actually retard an eruption and perhaps lessen its explosivity. The same implications discussed with respect to the contribution to degassing of magma (dependence of permeability and rock strength on the state and rate of healing) also apply to slope stability, only that here they are much more intimately linked to the distribution and orientation of the veins within the volcanic edifice. In the "fresh" state, where tuffisite veins are weaker than the host rock, they would presumably be destabilizing and might engender slope failure.
If, however, they reach a healed state where they become relatively strong, tuffisites may in fact strengthen the flanks of volcanoes as they would act as a strong and rigid structure introduced into an environment that is inherently fractured.

Our findings inherently surmise that tuffisites may recover their mechanical properties and exceed those of their materials of origin at the onset of fragmentation. With the expectation that such variability may evolve over relatively short timescales, we emphasize that numerical simulations are required to assess the structural stability and pressure changes that accompany the formation of tuffisites during an eruptive phase.

\section{Conclusions}

1. At eruptive temperatures $\left(940^{\circ} \mathrm{C}\right)$, the tested tuffisitebearing andesites deform in a strictly brittle manner and their UCS is independent of presence and/or orientation of tuffisite veins.

2. The permeability of tuffisite-bearing andesite decreases with confining pressure and depends on the orientation of tuffisite veins. For cases in which a rock contained coherent tuffisite veins perpendicularly to fluid flow, the permeability remained similar to the host rock; however, with tuffisite veins at 45 degrees to fluid flow, the permeability doubled at shallow depth, but decreased and recovered original values with increasing depth.

3. Our results report the physical properties of tuffisites in a recovered state and therefore the upper limit of UCS and the lower limit of permeability. At the point of formation and during the recovery process, these rocks might be weaker and more permeable and therefore have a different effect on the eruptive behavior.

Acknowledgements. We would like to thank Nick Varley for his essential support during the field campaign in Mexico and Ulrich Kueppers, Soureya Becker, Nicklas Berninger, Fabian Goldstein and Bahama John for help with the field work. We gratefully acknowledge John Bowles, Steve Boon, and Neil Hughes for help and support during experimentation (all at UCL), and Markus Sieber for his assistance at LMU. M. J. Heap and D. B. Dingwell acknowledge the support of a Hubert Curien Partnership (PHC) PROCOPE grant (grant number 27061UE), the Deutscher Akademischer Austauschdienst (DAAD) in Germany, and the Ministry of Foreign and European Affairs (MAE) and the Ministry of Higher Education and Research (MESR), both in France. Y. Lavallée acknowledges funds from the Deutsche Forschungsgemeinschaft grants LA2651/1-1 and LA2651/3-1. D. B. Dingwell also acknowledges support of a Research Professorship (LMUexcellent) of the Bundesexzellenzinitiative and the EVOKES (247076) advanced grant of the ERC. We would further like to thank Guido Giordano and Kathy Cashman for their thorough and constructive reviews, which helped to improve this manuscript. 
Edited by: P. Papale

\section{References}

Ben-David, O., Rubinstein, S. M., and Fineberg, J.: Slip-stick and the evolution of frictional strength. Nature, 463, 76-79, 2010.

Benson, P. M., Meredith, P. G., Platzman, E. S. and White, R. E.: Pore fabric shape anisotropy in porous sandstones and its relation to elastic wave velocity and permeability anisotropy under hydrostatic pressure, Int. J. Rock Mech. Min. Sci., 42, 890-899, 2005.

Cashman, K. V., Thornber, C. R., and Pallister, J. S.: From dome to dust; shallow crystallization and fragmentation of conduit magma during the 2004-2006 dome extrusion of Mount St. Helens, Washington, US Geological Survey Professional Paper, 387-413, 2008

Castro, J. M., Cordonnier, B., Tuffen, H., Tobin, M. J., Puskar, L., Martin, M. C., and Bechtel, H. A.: The role of melt-fracture degassing in defusing explosive rhyolite eruptions at volcán Chaitén, Earth Planet. Sci. Lett., 333-334, 63-69, 2012.

Cloos, H.: Bau und Taetigkeit von Tuffschloten; Untersuchungen an dem schwaebischen Vulkan. Trans. Stephan Kolzenburg. Geologische Rundschau, 32, 709-800, 1941.

Cocks, A. C. F.. Constitutive modelling of powder compaction and sintering. Prog. Mater. Sci., 46, 201-229, 2001.

Collinson, A. S. D. and Neuberg, J. W.: Permeability Controls on Gas Storage and Transport in a Permeable Volcanic Edifice, J. Volcanol. Geotherm. Res., in press, doi:10.1016/j.jvolgeores.2012.06.027, 2012.

Friedlander, E. A.: The nature and evolution of conduit faults in the 2004-2008 Mount St. Helens lava dome eruption, University of British Columbia, University of British Columbia, 2012.

Guéguen, V. and Palciauskas, V.: Introduction to the physics of rocks. Princeton University Press, Princeton, NJ, USA, 294 pp., 1994.

Heiken, G., Wohletz, K., and Eichelberger, J.: Fracture fillings and intrusive pyroclasts, Inyo Domes, California, J. Geophys. Res., 93, 4335-4350, 1988.

Hess, K.-U., Cordonnier, B., Lavallée, Y., and Dingwell, D. B.: High-load, high-temperature deformation apparatus for synthetic and natural silicate melts, Rev. Sci. Instr., 78, 4 pp.,, 2007.

Kendrick, J. E., Lavallee, Y., Ferk, A., Perugini, D., Leonhardt, R., and Dingwell, D. B.: Extreme frictional processes in the volcanic conduit of Mount St. Helens (USA) during the 2004-2008 eruption, J. Struct. Geol., 38, 61-76., 2012.

Kennedy, B. M., Jellinek, A. M., Russell, J. K., Nichols, A. R. L., and Vigouroux, N.. Time-and temperature-dependent conduit wall porosity: A key control on degassing and explosivity at Tarawera volcano, New Zealand, Earth Planet. Sci. Lett., 299, 126-137, 2010.

Kennedy, L. A., Russell, J. K., and Nelles, E.: Origins of Mount St. Helens cataclasites; experimental insights, Am. Mineral., 94, 995-1004, 2009.

Lavallée, Y., Benson, P., Heap, M., Flaws, A., Hess, K. U., and Dingwell, D. B.: Volcanic conduit failure as a trigger to magma fragmentation, Bull. Volcanol., 74, 11-13, 2012a.

Lavallée, Y., Varley, N. R., Alatorre-Ibarguëngoitia, M. A., Hess, K.-U., Kueppers, U., Mueller, S., Richard, D., Scheu, B., Spieler, O., and Dingwell, D. B. Magmatic architecture of dome-building eruptions at Volcán de Colima, Mexico, Bull. Volcanol., 74, 249_ 260, 2012b.

Nakada, S., Shimizu, H., and Ohta, K. Overview of the 1990-1995 eruption at Unzen Volcano, J. Volcanol. Geotherm. Res., 89, 122, 1999.

Noguchi, S., Toramaru, A., and Nakada, S.: Groundmass crystallization in dacite dykes taken in Unzen Scientific Drilling Project (USDP-4), J. Volcanol. Geotherm. Res., 175, 71-81, 2008.

Olgaard, D. L. and Fitz Gerald, J. D.: Evolution of pore microstructures during healing of grain boundaries in synthetic calcite rocks, Contrib. Mineral., Petrol., 115, 138-154, 1993.

Paterson, M. S. and Wong, T.-F.: Experimental rock deformation; the brittle field, Springer-Verlag, Berlin, Germany, 347 pp., 2005.

Petrakova, L., Heap, M. J., Lavallée, Y., Baud, P., Varely, N. R., and Dingwell, D. B.: The effect of thermal stresses on the strength and physical properties of edifice-forming andesites: the case study of Volcan de Colima, J. Volcanol. Geotherm. Res., in review, 2012.

Quane, S. L. and Russell, J. K.: Welding; insights from hightemperature analogue experiments, J. Volcanol. Geotherm. Res., 142, 67-87, 2005.

Reubi, O. and Blundy, J.: Assimilation of plutonic roots, formation of high-K 'exotic' melt inclusions and genesis of andesitic magmas at Volcan de Colima, Mexico, J. Petrol., 49, 2221-2243, 2008.

Russell, J. K. and Quane, S. L.: Rheology of welding; inversion of field constraints, J. Volcanol. Geotherm. Res., 142, 173-191, 2005.

Savov, I. P., James, F. L., and Navarro-Ochoa, C.: Petrology and geochemistry of lava and ash erupted from Volcán Colima, Mexico, during 1998-2005, J. Volcanol. Geotherm. Res., 174, 241256, 2008.

Shepherd, R. G.: Correlations of permeability and grain size, Ground Water, 27, 633-638, 1989.

Stasiuk, M. V., Barclay, J., Carroll, M. R., Jaupart, C., Ratte, J. C., Sparks, R. S. J., and Tait, S. R.: Degassing during magma ascent in the Mule Creek vent (USA), Bull. Volcanol., 58, 117-130, 1996.

Taisne, B. and Jaupart, C.: Magma degassing and intermittent lava dome growth, Geophys. Res. Lett., 35, L20310, doi:10.1029/2008GL035432, 2008.

Taran, Y. A., Bernard, A., Gavilanes, J. C., Lunezheva, E., Cortes, A., and Armienta, M. A.: Chemistry and mineralogy of hightemperature gas discharges from Colima volcano, Mexico. Implications for magmatic gas-atmosphere interaction, J. Volcanol. Geotherm. Res., 108, 245-264, 2001.

Tuffen, H., Dingwell, D. B., and Pinkerton, H.: Repeated fracture and healing of silicic magma generate flow banding and earthquakes?, Geology, doi:10.1130/G19777.1, 31, 1089-1092, 2003.

Venkatachari, K. R. and Raj, R.: Shear deformation and densification of powder compacts, J. Am. Ceram. Soc., 69, 499-506, 1986.

Vinciguerra, S., Trovato, C., Meredith, P. G., and Benson, P. M.: Relating seismic velocities, thermal cracking and permeability in Mt. Etna and Iceland basalts, Int. J. Rock Mech. Min. Sci., 42, 900-910, 2005.

Wang, W., Fu, Z., Wang, H., and Yuan, R.: Influence of hot pressing sintering temperature and time on microstructure and mechanical properties of TiB2 ceramics, J. Eur. Ceram. Soc., 22, 1045-1049, 
2002.

Zou, R. P., Gan, M. L., and Yu, A. B.: Prediction of the porosity of multi-component mixtures of cohesive and non-cohesive particles, Chem. Eng. Sci., 66, 4711-4721, 2011. 